http://doi.org/10.35784/iapgos.1922

\title{
DISASSEMBLABLE VACUUM CHAMBER AS AN INNOVATIVE TEST STAND DESIGNED FOR RESEARCH ON IMPROVING THE OPERATIONAL PARAMETERS OF POWER SWITCHING APPARATUS
}

\author{
Michał Lech \\ Lublin University of Technology, Faculty of Electrical Engineering and Computer Science, Lublin, Poland
}

Abstract. The Polish power industry is characterized by outdated elements and is in poor technical condition. This applies mainly to overhead lines operating at medium and high voltage (MV and HV) levels. Moreover, the Energy Regulatory Office (ERO) requires the Distribution System Operators to supply electricity with specified parameters, ensuring uninterrupted electricity supply to end users. Failure to meet these conditions results in specific financial penalties. In connection with the above, there is a strong need to upgrade the existing electricity grids using modern equipment. The article presents an innovative, original research position based on the so-called dismountable vacuum chamber, which allows research to be conducted on improving the performance of modern switching equipment used in Smart Grid networks. The article also presents the results of electric strength tests of the inter-contact break in order to confirm the correctness of operation of the described test stand.

Keywords: vacuum breakdown, vacuum switchgears, vacuum technology, electric strength

\section{ROZBIERALNA KOMORA PRÓŻNIOWA JAKO INNOWACYJNE STANOWISKO BADAWCZE PRZEZNACZONE DO BADAŃ NAD POPRAWĄ PARAMETRÓW EKSPLOATACYJNYCH ELEKTROENERGETYCZNEJ APARATURY LACCZENIOWEJ}

\begin{abstract}
Streszczenie. Polska elektroenergetyka cechuje sie elementami przestarzatymi oraz $w$ złej kondycji technicznej. Dotyczy to przede wszystkim lini napowietrznych pracujacych na poziomie średnich $i$ wysokich napięć (SN $i$ WN). Co więcej, Urząd Regulacji Energetyki (URE) wymaga od Operatorów Systemu Dystrybucyjnego dostarczania energii elektrycznej o określonych parametrach, zapewniajacych odbiorcom końcowym bezprzerwowe dostawy energii elektrycznej. Niespetnienie tych warunków skutkuje określonymi karami finansowymi. W związku z powyższym istnieje silna potrzeba modernizacji istniejacych sieci elektroenergetycznych z wykorzystaniem nowoczesnej aparatury. W artykule przedstawiono innowacyjne, autorskie stanowisko badawcze oparte o tzw. rozbieralna komorę próżniową, które umożliwia przeprowadzenie badań nad poprawa parametrów eksploatacyjnych nowoczesnej aparatury tączeniowej wykorzystywanej w sieciach Smart Grid. Przedstawiono również wyniki badań wytrzymałości elektrycznej przerwy międzystykowej celem potwierdzenia poprawności działania opisanego stanowiska badawczego.
\end{abstract}

Słowa kluczowe: przebicie elektryczne w próżni, próżniowa aparatura łączeniowa, technologia próżniowa, wytrzymałość elektryczna

\section{Introduction}

Currently, the most frequently used centres of work and electric arc extinguishing in medium-voltage switchgear (disconnectors, switches) are based on sulphur hexafluoride (SF6) and a vacuum (fig. 1, fig. 2). The problems with the use of SF6 gas result mainly from its properties which are harmful to the climate.

It is an odourless, colorless (under normal conditions), nonpoisonous and non-flammable gas. However, it has been classified as a fluorinated greenhouse gas (F-gas), which, while being in the atmosphere for a longer period of time, influences the temperature rise. Moreover, it is the strongest greenhouse gas known to date. Its global warming potential (GWP) is 22200 , which means that $22,200 \mathrm{~kg}$ of carbon dioxide has the same effect as $1 \mathrm{~kg}$ of sulphur hexafluoride. The full decomposition of this gas in the atmosphere takes 3200 years.
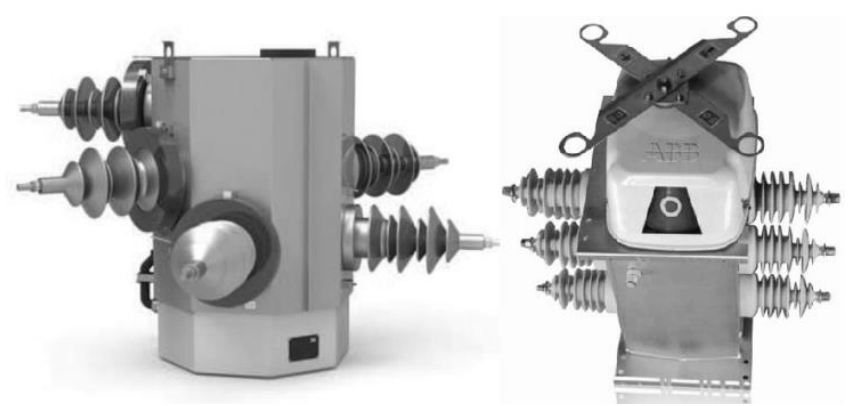

Fig. 1. Medium-voltage switchgear using as insulating medium SF6: THO disconnector, made by ZPUE and SECTOS disconnector, made by ABB

The use of sulphur hexafluoride has not gone unnoticed by various organisations and institutions. The Montreal Protocol, signed in 1987 [8], provides for the prevention of the ozone hole and also introduces the necessity to reduce the use of the substances which destroy this ozone hole is. The Kyoto Protocol, in force since 2005, also assumes the reduction of F-gas emissions [5]. The current plan assumes the reduction of gas emissions by $80-95 \%$ by 2050 . The European Union has also formulated appropriate action plans related to environmental protection. The regulation related to fluorinated greenhouse gases provides for a reduction of gas emissions in the European Union countries by about $73 \%$ by 2030 and by about $75 \%$ by 2050 compared to 1990 levels.
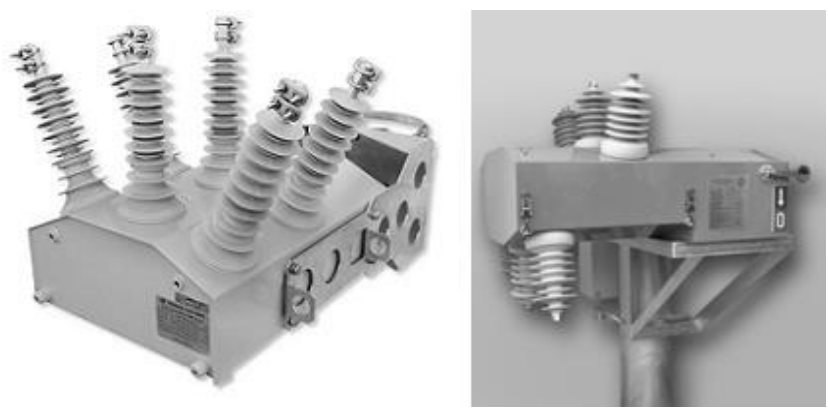

Fig. 2. Medium-voltage switchgear using a vacuum as an insulating medium: KTR recloser manufactured by Tavrida Electric and EKTOS disconnector manufactured by EKTO and Lublin University of Technology

An excellent alternative to the abovementioned SF6 gas is vacuum technology. Currently, there is no other environmentally friendly extinguishing medium in use in switchgear. Vacuum extinguishing interrupters are characterized by high switching durability, any working position, quick recovery of electrical strength and no explosion hazard [11].

The demand for new, innovative devices meeting a number of growing requirements related to the reliability of electricity distribution requires newer solutions. A number of new opportunities in terms of research on prototypes of new, innovative devices lead to the research position described in this article based on a so-called disassemblable vacuum chamber. 


\section{Electrical breakdown in vacuum}

According to the definition, a vacuum in the literal sense is a space completely devoid of matter. In technical terms, it is a state of high dilution of gas.

In the case of a gas pressure of a value at which the average free path of electrons and molecules is greater than the contact distance, the development of electron avalanches, which initiate an electric leap, is impossible. The mean free paths of electrons $L_{\mathrm{e}}$ and molecules $L_{\mathrm{cz}}$ in gas can be calculated using the following relationships $[3,7]$ :

$$
\begin{aligned}
L_{c z} & =2.27 * 10^{-5} \frac{T}{p} \\
L_{e} & =1.29 * 10^{-4} \frac{T}{p}
\end{aligned}
$$

where $T$ is the absolute gas temperature and $p$ is the gas pressure.

Taking air as a gas consisting mainly of nitrogen and oxygen, it has been calculated that for an average electron-free pathway and a gas molecule of $10 \mathrm{~mm}$, the gas pressure should be $3.8 \mathrm{~Pa}$ and $0.67 \mathrm{~Pa}$, respectively. In such a situation, the development of an electron avalanche is impossible due to the fact that each electron reaches the anode unhindered. Therefore, the initiation of an electrical surge in a vacuum environment is possible through the existence of physical phenomena other than electron avalanches.

In fact, the initiation of an electrical surge in a vacuum environment is caused by the interaction of several physical phenomena. The basic condition for the development of a discharge in a vacuum is the presence of carriers of electric charges and molecules or vapours which, after ionisation, will cause the current to increase to an appropriate value.

There are many hypotheses of the process of initiation and development of a leap in a vacuum environment, which can be divided into the following groups [9]:

- Hypotheses of mechanisms of exchange of charged particles In these hypotheses, it is assumed that a random electron located in the inter-contact space, accelerated by the action of an electric field, knocks positive ions and photons out of the anode, and these in turn knock subsequent electrons out of the cathode $[6,7,13]$. In this case, cumulative ionization is assumed to occur and thus an electrical breakdown. The criterion for the development of the discharge in these hypotheses has the following form:

$$
A B+E F \geq 1
$$

where $A$ is the number of positive ions ejected from the anode by one electron, $B$ is the number of electrons released from the cathode by one positive ion, $E$ is the number of negative ions produced by one positive ion and $F$ is the number of positive ions produced by one negative ion.

- Hypotheses of mechanisms initiating an electrical breakdown over the field emission of electrons

The hypotheses in this group assume the occurrence of microsharpening on the cathode surface and thus an increase in the electric field strength $[1,4,10,14]$. Thanks to this, field emission of electrons and thus subsequent phenomena that may lead to electric discharge is possible. The hypotheses in this group are based on two mechanisms deciding on the electrical breakdown: the anode mechanism, consisting in heating the anode, and the cathode mechanism, consisting in heating the cathode.

- Hypotheses of mechanisms initiating electrical breakdown through micro-particles

The hypotheses included in this group are characterized by the assumption that charged microparticles break away from the electrodes and then move due to electrostatic forces.

As a result of this movement, their kinetic energy increases. If the kinetic energy of a microparticle is high enough, after a collision with the opposite electrode, its material evaporates due to an increase in temperature or the emission of subsequent lumps of material. These phenomena may cause the development of electrical discharge. The criterion of initiating an electrical breakdown according to this hypothesis was determined by Cranberg using the following relation [2]:

$$
E_{p} U_{p}=C_{k}
$$

where $E_{\mathrm{p}}$ is the average current of the macroscopic electric field at the point where the microparticle breaks off at $U$ voltage at the terminals of the system equal to the voltage of breakdown and $C_{\mathrm{k}}$ is a constant proportional to the critical energy density in the impact area of the microparticle, depending on the material and surface condition of the electrode.

- Hypothesis of desorption mechanism of jump initiation This hypothesis says that for pressures between $10^{-5} \div 10^{-2} \mathrm{~Pa}$, there is a layer of impurities and gases on the walls of the vacuum interrupter and on the electrode surfaces. After applying voltage of an appropriate value to the poles of the chamber, a desorption of neutral particles and ions occurs, caused by the action of an electric field and an increase in the surface temperature. With an appropriate number of gas molecules in the inter-electrode space, the discharge develops and then the desorption process is repeated so that the final electrical breakdown between the electrodes takes place [12].

\section{Test stand}

The basic element of the test stand is a discharge chamber equipped with a contact system in which the contacts are made of tungsten filtered with copper at a ratio of $70 \% \mathrm{~W}$ to $30 \% \mathrm{Cu}$. The innovativeness of the stand is manifested in the way it is made, namely in allowing free access to the interior of the chamber Thanks to this, it is possible to change the contact pads, which provides many possibilities for future research, which includes determining the influence of the type of contact materials on the electrical strength of the contact break and on the burning process of the electric arc in the chamber. Additionally, the discharge chamber has been equipped with glass sight windows thanks to which it will be possible to precisely analyse the processes taking place inside the chamber with the use of, among others, an ultrafast camera or an optical fiber spectrophotometer. The stand is also equipped with a contact distance adjustment system, consisting of an integrated mobile contact unit with an actuator and a displacement sensor. The contact distance can be set by means of buttons located on the operator's panel or by means of a remote control to ensure safe operation. The value of the specified contact distance is displayed on an LCD display attached to the stand's structure, which has been designed and made in a mobile way and ensures failure-free work. A view of the test stand is shown in Fig. 4.

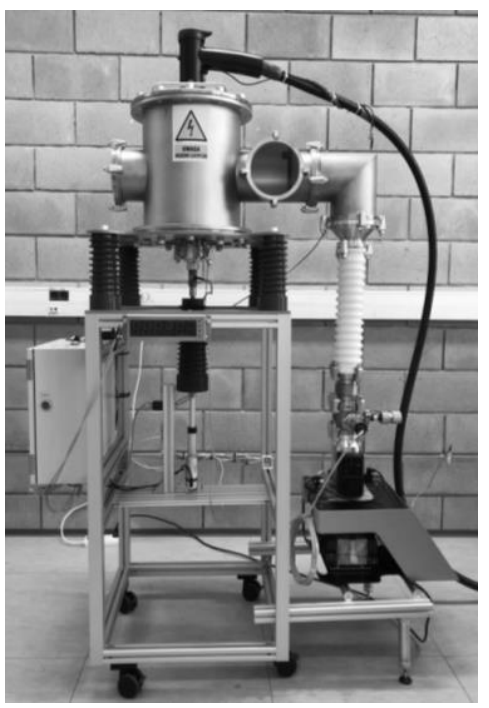

Fig. 4. Research stand based on the so-called disassemblable chamber 
In order to obtain a vacuum of a specific pressure inside the disassemblable chamber, a vacuum system is used, consisting of a set of vacuum pumps (turbomolecular and vacuum) with a capacity of $90 \mathrm{l} / \mathrm{s}$, a dedicated vacuum meter and a manual valve enabling the maintenance of a specific pressure value. The construction of the test stand is also equipped with a dedicated platform on which the set of vacuum pumps can be placed in a stable way.

The power supply kit for this test stand consists of a high voltage transformer with a maximum output voltage of $50 \mathrm{kV}$ and a nominal power rating of $2.5 \mathrm{kVA}$, in a paper-oil insulated resin housing, equipped with a two-section primary winding, allowing the transformer gearbox to be changed for two secondary voltage ranges. The transformer works with a dedicated control panel with a rated power of $6 \mathrm{kVA}$. Precise voltage measurement is enabled by a capacitive divider, designed and manufactured based on lowloss polypropylene capacitors. The internal equipment of the control panel is mainly a brush voltage regulator with a drive and a SIMATIC S7 1200 PLC with a dedicated measuring module, which is responsible for the control part. Convenient and safe operation is ensured by using the HMI operator panel and a set of indicator lamps and buttons. The power supply for the test stand was provided using a YHAKXS $1 \times 120 / 50$ type power cable terminated with an angular connector head. A view of the test set is shown in Fig. 5, while the electrical diagram of the complete test system is shown in Fig. 6.

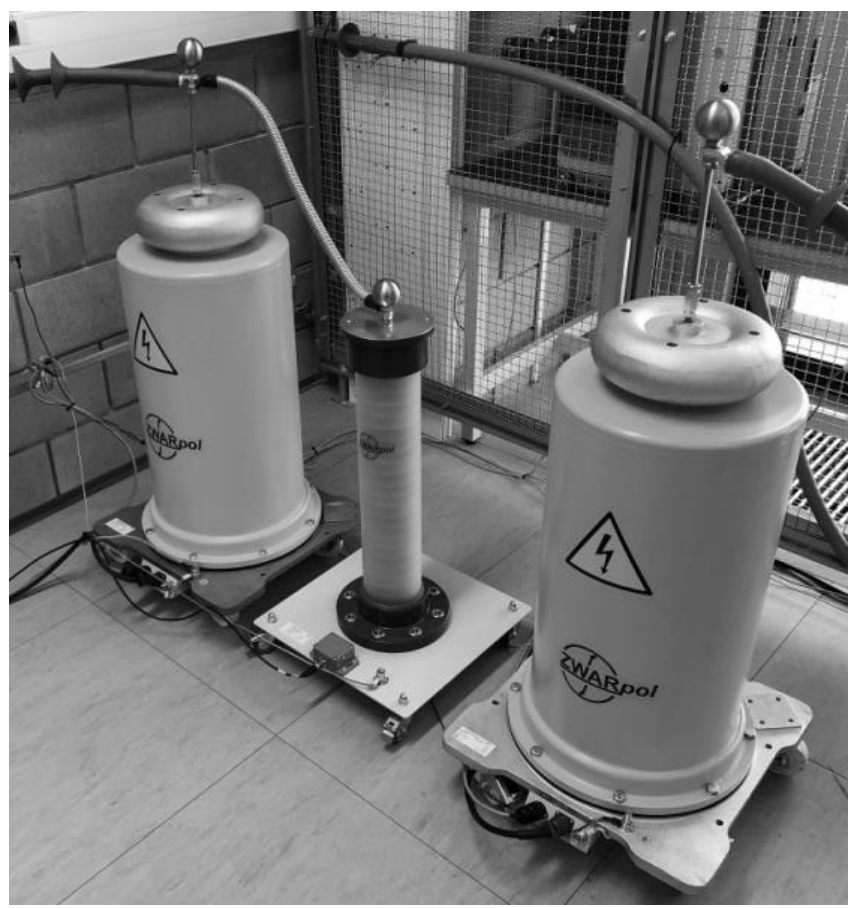

Fig. 5. Test set to supply the test bench

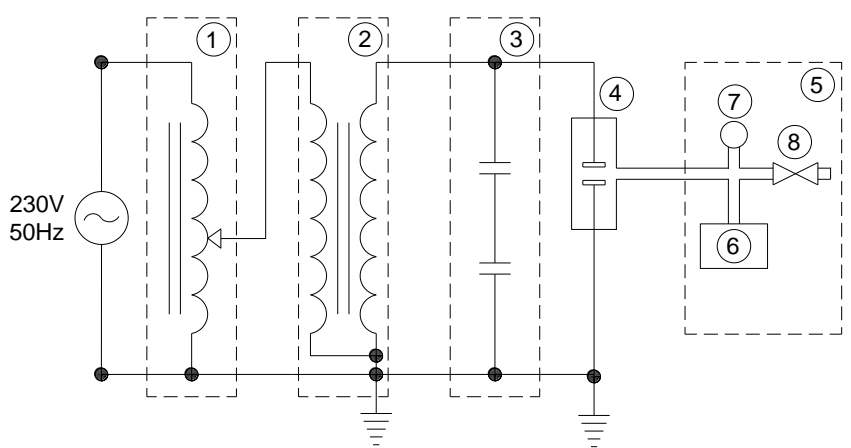

Fig. 6. Electrical diagram of the system for testing electrical strength of vacuum chambers $(1$ - control panel, 2 - supply transformer, 3 - capacitive dividers, 4 - discharge chamber, 5 - vacuum system, 6 - set of vacuum pumps, 7 - vacuum meter, 8 - manual vacuum valve).

\section{Results of electrical strength tests}

Tests of the electrical strength of the inter-contact break in the tested discharge chamber for contact distances in the range of $2 \div 5 \mathrm{~mm}$ for pressures were performed in the range of $4.0 \times 10^{-4} \div 4.4 \times 10^{2} \mathrm{~Pa}$.

Figure 7 shows the relationship between the electrical strength of thrust $U_{\mathrm{d}}$ as a function of pressure $p$. It can be seen that for pressures below $3 \times 10^{-1} \mathrm{~Pa}$, the breakthrough voltage in the discharge chamber maintained a constant value of approximately $17,23,31$ and $33 \mathrm{kV}$ for contact distances of 2, 3, 4 and $5 \mathrm{~mm}$, respectively. The described relation creates a safe zone for the vacuum chamber, which guarantees failure-free operation of the switching equipment using vacuum extinguishing chambers. When increasing the pressure values above $3 \times 10^{-1} \mathrm{~Pa}$, there was a rapid drop in the values of the breakthrough voltages, whose values were the same for each contact distance. From a pressure value of $5 \times 10^{1} \mathrm{~Pa}$, the minimum value of the breakthrough voltage of approx. $0.3 \mathrm{kV}$ was reached.

Figure 8 shows the relation of the breakthrough voltage as a function of the contact distance for selected pressures.

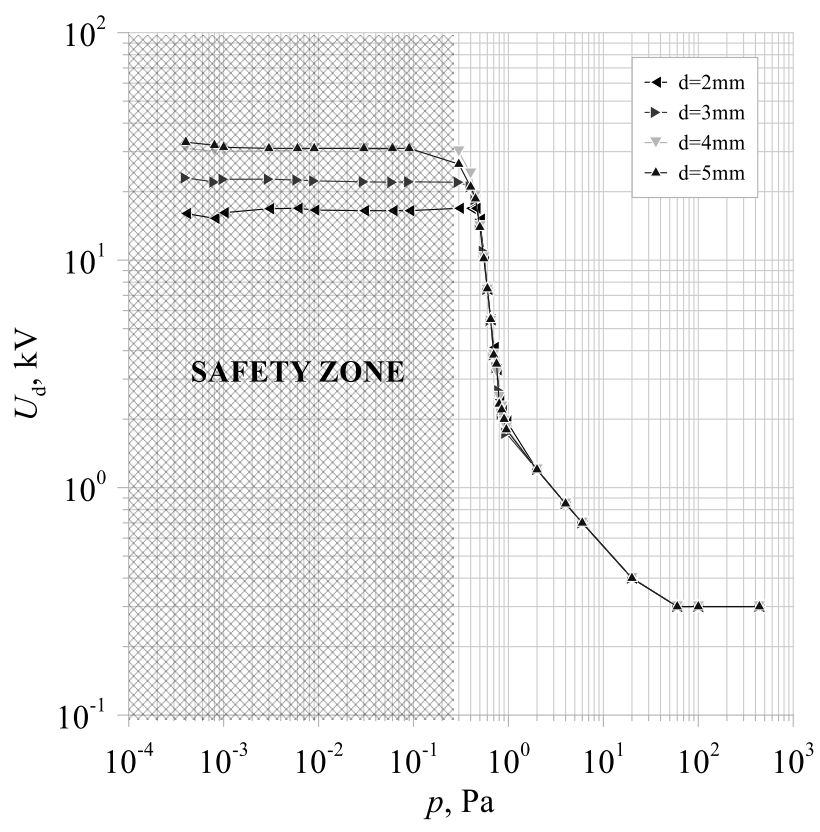

Fig. 7. Relation of breakdown voltage $U_{d}$ as a function of pressure $p$ for selected contact distances $d$

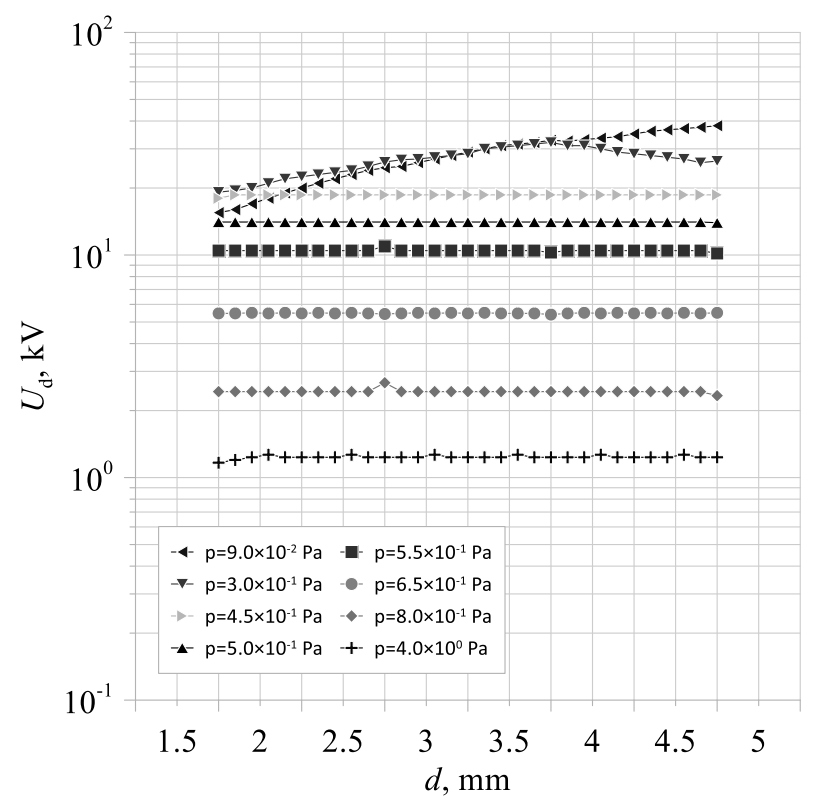

Fig. 8. Breakdown voltage dependence $U_{d}$ as a function of distance inter-contact $d$ for selected pressure values $p$ 
When interpreting the above characteristics, it can be seen that at lower pressures inside the tested discharge chamber, the value of the breakthrough voltage is mainly influenced by the contact distance. When the chamber is gradually aerated, the characteristics are flattened so that from pressure values equal to $4,5 \times 10^{-1} \mathrm{~Pa}$, they are completely horizontal. This shows that the value of the breakdown voltage for certain pressures is not affected by the inter-contact distance.

\section{Conclusions}

The innovative test stand based on the so-called disassemblable vacuum chamber is an original stand designed and built for the purpose of conducting research on improving the operational parameters of electrical switching equipment. Its use creates an opportunity to examine, among other things, the influence of the content of various gas mixtures in the discharge chamber, the material of electrodes and their construction on the discharge processes taking place in the inter-electrode space. Thanks to the design of glass sight windows, it is possible to observe the arc processes taking place in the chamber in detail. For this research, an ultra-fast camera and a fiber-optic spectrophotometer will be used.

The conducted tests of the electric strength of the inter-contact break confirm the correctness of the described test stand. The analysis of the obtained characteristics confirms the previously known laws and relationships related to the properties of vacuum insulation systems.

\section{References}

[1] Boyle W.S., Kisiluk P., Germer L.H.: Electrical break down in high vacuum. J. Appl. Phys. 26/1955, 270.

[2] Cranberg L.: The initiation of electrical breakdown in vacuum. J. Appl. Phys. 23/1952, 518

[3] Hałas A., Technologia wysokiej próżni. PWN, Warszawa 1980.

[4] Hawley R.: Vacuum as an isulator. Vacuum 10/1960, 310

[5] Kyoto Protocol to the UN Framework Convention on Climate Change, Kyoto, Kyoto 1997.

[6] Mansfield W.K.: Prebreakdown conduction in continuously pumped high vacuum systems. Brit. J. Appl. Phys. 11/1960, 454.

[7] Mansfield W.K.: Prebreakdown conduction in continuously pumped high vacuum systems, $\mathrm{Ph}$. D. Thesis, University of London, 1961.

[8] Montreal Protocol on Substances that Deplete the Ozone Layer, Montreal, 1987

[9] Opydo W.: Właściwości gazowych i próżniowych wysokonapięciowych układów izolacyjnych, Wydawnictwo Politechniki Poznańskiej, Poznań 2008.

[10] Schmidt G.: Electrical discharges in high vacuum. Acta Phys. Hungar. 9/1958, 1.

[11] Slade P. G.: The Vacuum Interrupter Theory, Design and Application, CRC Press 2007.

[12] Tarasova L.V.: Desorbcionnyj mehanizm eletriceskogo proboa v vakuume, Doklady AN SSSR, 167/1966, 330.

[13] Van Atta L.C., Van De Graaf R.J., Barton H.A.: A new design for a high voltage dis charge tube. Phys, Rev. 43/1933, 158

[14] Wijker W.J.: The electrical breakdown in vacuum. Appl. Sci. Res. 9/1961, 1.

\section{M.Sc. Eng. Michal Lech \\ e-mail: m.lech@pollub.pl}

Michał Lech (born 1995, Kielce) - PhD student at the Doctoral School at the Lublin University of Technology. His scientific interests include innovative methods of designing and constructing devices operating in Smart Grid networks which increase the reliability of electricity transmission and distribution. His current scientific research concerns improving the operational parameters of SF6 free switching equipment.

https://orcid.org/0000-0002-4732-2459

otrzymano/received: 19.05 .2020 